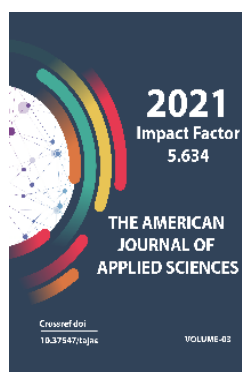

\title{
Slinging Unit For A Hollow-Core Floor Slab Of Stand-Off Formwork
}

Pulat Mirzaev

Candidate Of Technical Sciences, Professor, Department Of Building Structures, Faculty Of Construction Of Buildings And Structures, Tashkent Institute Of Architecture And Civil Engineering, Uzbekistan

\footnotetext{
Journal Website: https://theamericanjou rnals.com/index.php/ta jas

Copyright: Original content from this work may be used under the terms of the creative commons attributes 4.0 licence.
}

\section{ABSTRACT}

Due to the fact that hollow-core slabs without formwork are produced without slinging loops (features of manufacturing technology), the issue of installation and transportation of these slabs has been solved. A constructive and technological solution is proposed for a slinging unit, arranged in the body of the slab, without the use of a slinging loop, and having only an anchor rod-dowel through which it is possible to directly sling the slab without using traditional slinging loops. The unit is designed with a reduced metal consumption and does not change the technology for manufacturing hollow-core slabs without formwork. Found and summed up a theoretical basis for calculating the bearing capacity of the proposed slinging unit, arranged in a hollow-core slab without formwork. It was revealed that the bearing capacity of the proposed slinging assembly, arranged in the body of a hollow-core slab, under the action of assembly loads, depends on the force of splitting the concrete of the protective layer located above the anchor rod-dowel of this assembly (all other things being equal). The theoretical data of the study were verified by full-scale tests of plates with slinging units arranged in their body, carried out in accordance with the proposed constructive and technological development. A utility model patent was obtained for the development of a loopless slinging unit for a hollow-core slab without formwork.

\section{KEYWORDS}

Loopless slinging assembly, hollow-core slab, form-less molding, dowel bar, load-bearing capacity, testing. 


\section{INTRODUCTION}

The imperfection of hollow-core slabs without formwork - the absence of slinging loops, leading to problems when lifting, installing these slabs, reduces the safety of construction work. When installing and lifting such plates without slinging loops, special load-handling devices are used. The use of such devices in construction presents certain difficulties, since it is required to create a park of load-gripping devices and workshops for their maintenance [1]. In addition, there are no such devices in construction trusts and firms in the country. Loopless slinging using load-gripping devices significantly save steel consumption. However, the competitiveness of load-gripping devices when installing hollow-core slabs without formwork is low, due to the fact that slinging with a hook and loop is versatile and easy to process. In this regard, with the transition of precast concrete enterprises to the technology of stand-off formwork molding, it became necessary to develop slinging assemblies in the slab body, taking into account their manufacture using this technology. In [2, Fig. 2] and [3, Fig. 3], a slinging unit is proposed for a hollow-core slab without formwork with crossshaped loops, the design of which is two reinforcing bars intersecting under the unit 900, located in the middle part along the height of the slab section. The rods of the cruciform loops are inserted along their entire length into the freshly formed body of the striped concrete massif through its lateral face (the configuration of the massif section is the section of a hollow-core slab). At the intersection of the rods on the upper shelf of the slab (above the void), a groove is formed through which the rods are gripped by the hook of the cargo sling (Fig. 1).

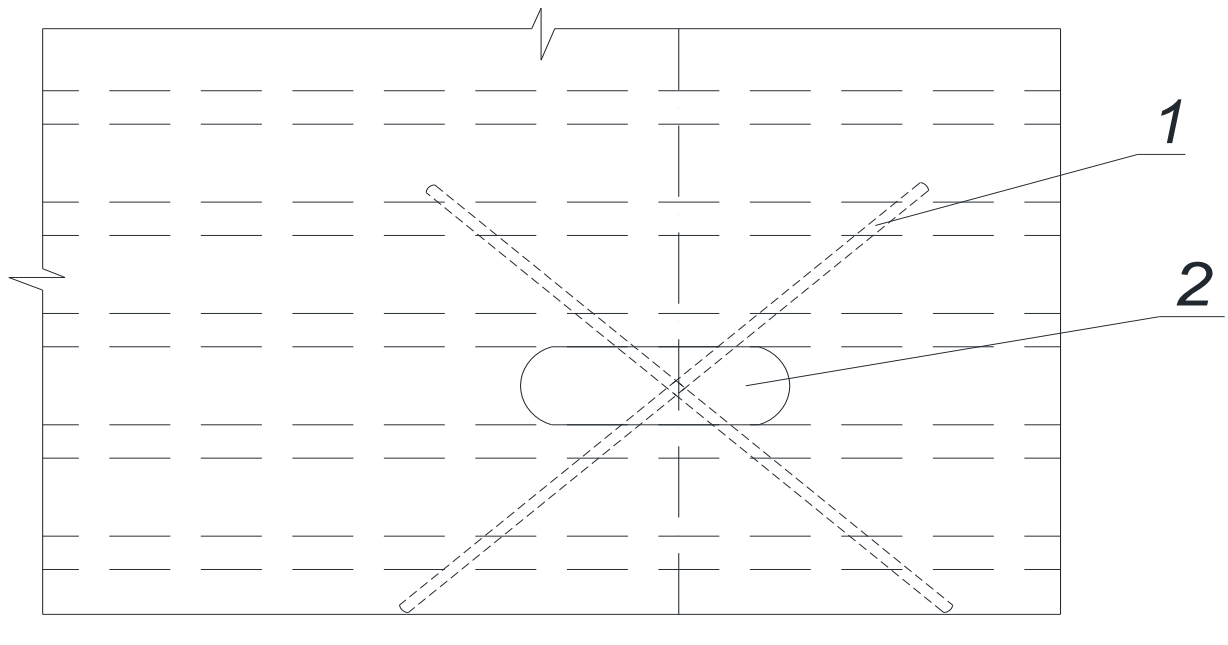

Fig.1. Arrangement of cross-shaped loops in a hollow-core slab without formwork [2, 3]: 1 cross-shaped hinges made of reinforcing bars; 2 - a groove in the upper shelf of the slab through which the cruciform rods are gripped at their intersection (in the void) by the hook of the cargo sling.

The invention [4] proposes a slinging unit in the plate also with cruciform loops. The difference between this slinging unit from [3] differs in the technology of the device of the slinging unit in the plate. In [5, fig.3] show a constructive solution of a slinging unit in a 
precast plate without formwork molding. A groove is formed on the upper shelf (by the collapse of the concrete of this shelf over the void), through which a loop grip from a bent reinforcing bar is placed into the void. Through the groove, the fenced off section of the void, representing the future body of the slinging unit, is filled with a concrete mixture so that it is possible to grip the loop with a slinging hook (Fig. 2). The device of slinging nodes $[3,4,5]$ is complicated, and these nodes have an increased metal consumption and labor intensity of their creation.

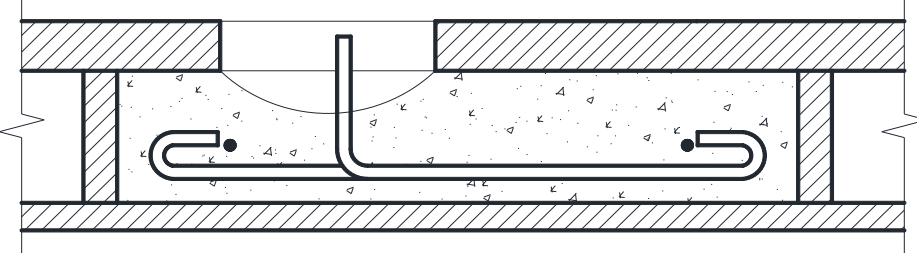

Fig. 2. Slinging knot, with a slinging loop, arranged in the hollow of the slab - proposal [5, fig. 3]

In [6], a slinging assembly in a non-formmolding plate is proposed, which contains at least one anchor and a mounting loop, installed along mutually intersecting planes (Fig. 3). A closed mounting loop proposed in [7] is used here. It is a modification of traditional mounting loops recommended by Technical Conditions TR94-2003 "Slinging loops of precast concrete and reinforced concrete structures, design, calculation and testing". NIIZHB. Moscow. 2003. The mounting loop and part of the anchor are embedded in the slab with reclaimed concrete, while the rest of the anchor is placed in the slab body (primal concrete). In this solution, a slinging assembly is complicated, consisting of an anchor and a mounting (slinging) loop, which increases the metal consumption of the slab. In addition, the results of testing plates for assembly loads with the device of such slinging assemblies are not given.
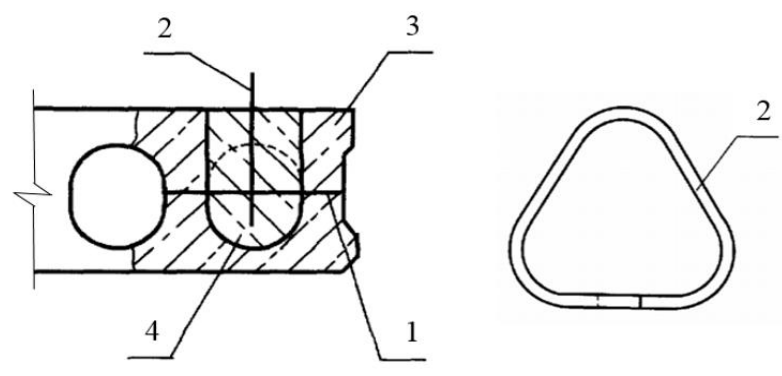

Fig.3. Slinging knot proposed [6]: 1 - anchor connecting the concrete of the primary filling (concrete of the slab) and the concrete of the secondary filling (concrete for sealing the void space at the section of the slinging unit); 2 - closed mounting loop; 3 - concrete of primary filling; 4 - secondary filling concrete. 
In [8, Fig. 4], a slinging assembly is considered, where the anchoring part of this mounting

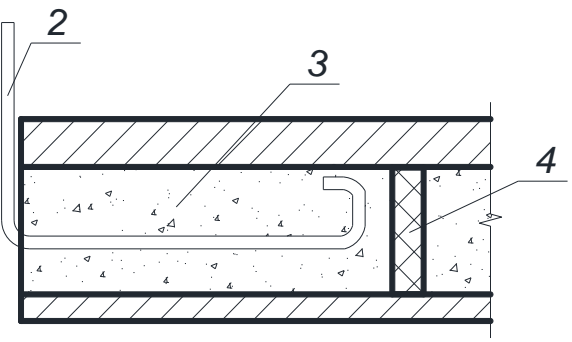

loop is arranged in the void of the end section of the slab (Fig. 4).

Âèä 1-1

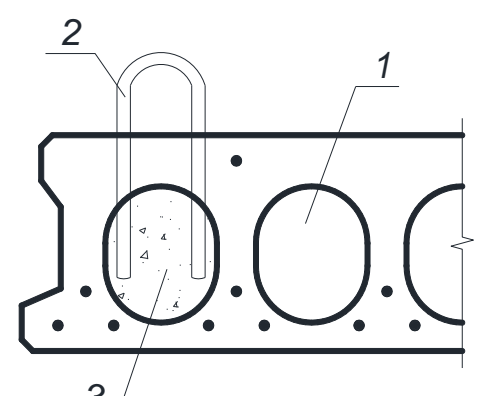

3

Fig.4. Diagram of a unit with a slinging loop in a hollow-core slab without formwork, proposed [8, Fig. 4]: 1 - emptiness; 2 - slinging loop with one-sided anchor; 3 - monolithic concrete; 4 plug-insert (foam).

Analyzing the results of tests of hollow-core floor slabs for assembly loads using such loops at the ends of the slabs, the authors of [8] note in their conclusions about additional research on their work.

The purpose of the work is to simplify the slinging (gripping) of a hollow-core slab without formwork during: removing the stand from the pallet for storage, transporting it to construction, installing the slab in the floor of a building under construction. To do this, it is necessary to arrange a slinging unit in the slab, which has an uncomplicated device, low metal consumption and labor intensity, high reliability, which does not create an obstacle to the technological process of manufacturing the slabs.

\section{METHODOLOGY}

\section{Method for determining the strength of the slab slinging unit}

For the possibility of slinging a hollow-core slab without formwork, a loopless slinging unit with one anchor is proposed, which is a smooth rod $350 \mathrm{~mm}$ long, made of hot-rolled reinforcement of class A240, through which it is possible to directly sling the slab without using traditional slinging loops (Fig. 5). 
à)

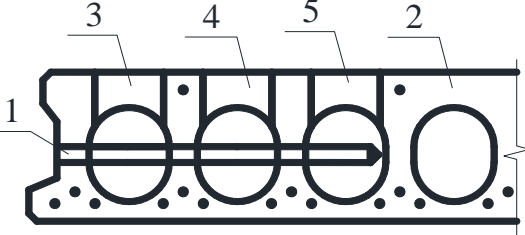

$\tilde{n})$

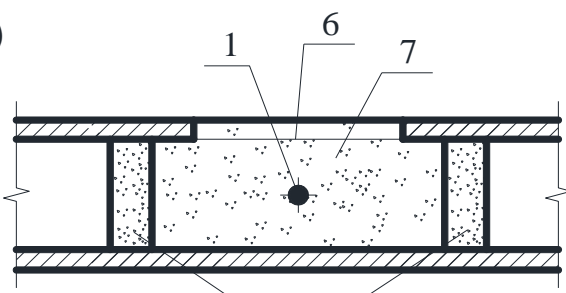

b)

$3 \quad 1-1$

4

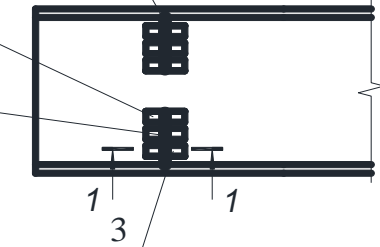

d)

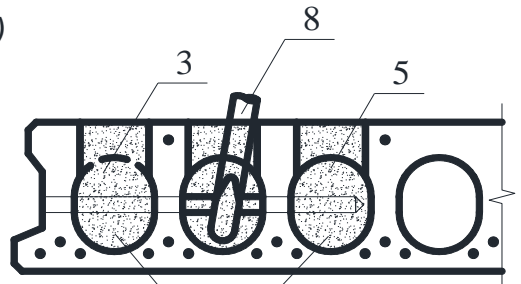

6

Fig.5. Arrangement of a loopless slinging assembly in the body of a hollow-core slab without formwork

The pointed end of the anchor 1 is inserted to its full length into the freshly formed body of the concrete strip array 2 on the stand through its lateral edge, crossing three edges and three voids (Fig. 5, a). Placing the anchor 1 into the freshly formed concrete of the massif 2 does not complicate and does not pose an obstacle to the technology of slab production. At the site of pushing the anchor 1 into the concrete of the massif 2 (on the upper flange), grooves are formed associated with the production technology of formless molding: 3 - above the extreme void, 4 - above the first intermediate void, 5 - above the second intermediate void (Fig. 5, b).

Parts of the anchor 1 located in the extreme and second intermediate voids are sealed with concrete of 6 class B30 through grooves 3 and 5 (Fig. 5, c and d). Before the concrete is embedded in the free parts of the anchor 1 in the voids, plugs-liners 7 made of foam plastic are installed in them to prevent the spreading of the concrete mixture in the voids (Fig. 5, c).

Through the groove 4, the slab is slinged with a hook 8 of the cargo sling through the middle part of the anchor 1 , located in the space of the first intermediate void (Fig. 5, d).

The design scheme of a rod - anchor embedded in the concrete body of the slab can be conventionally represented as a rod - a dowel, which is under the influence of a transverse force from assembly loads. 


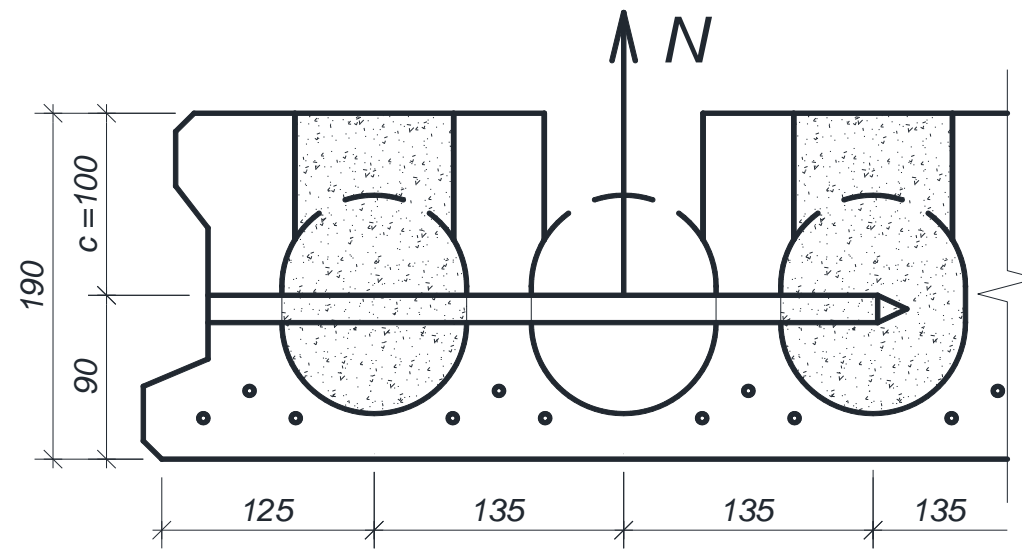

Fig.6. Design diagram of the operation of the anchor rod of the proposed slinging unit in a hollow-core slab of non-formwork molding

In connection with such a design scheme, the authors of [9] argue that there are two types of exhaustion of the shear resistance:

- $\quad$ First - reaching the yield point of steel of the rod-dowel and crushing the concrete above it;

- $\quad$ The second - splitting of concrete over the dowel rod in the section of its length (in the section of the slinging unit).

Further, the authors cite the following dependence [9, formula 4.6] cited from [10], according to which it is possible to determine the bearing capacity of the rod-dowel corresponding to the destruction of the node from the simultaneous crushing of concrete and reaching the yield strength of the steel rod with the statement that this formula satisfactorily describes the bearing the ability of the dowel for the first type of exhaustion of the dowel shear resistance.

$$
D_{u}=K \cdot d_{b}^{2} \sqrt{f_{c c} \cdot f_{s y}}
$$

$D_{u}$ - Bearing capacity of the dowel rod;

$d_{b}$ - Rod diameter; $f_{c c}$ - Compressive strength of concrete;

$f_{s y}$ - The yield point of the rod-dowel steel

Preliminary calculations according to formula (1) given in [10] showed that it is unsuitable for determining the bearing capacity of a slinging unit with an anchor rod-dowel, arranged in a slab, due to the low height of this slab. This formula applies to the case when the anchor rod-dowel is arranged in a structure with a strong concrete mass, which causes the destruction of the slinging rod as a result of reaching the yield point of steel by the roddowel and crushing of concrete over the dowel.

Experiments have shown [11] that at $c \geq$ $(6-7) d_{b}$ (where $c$-is the thickness of the protective layer of concrete), the depletion of the shear resistance occurs from the yield of the steel of the rod-dowel and crushing of concrete. In this regard, the authors of [9] note that the thickness of the protective layer of concrete $\langle C\rangle$ is the main parameter on which the second type of exhaustion of the shear 
resistance depends - on the splitting of concrete.

In [12] to determine the bearing capacity of the rod-dowel, depending on the force of splitting the concrete of the protective layer, the following formula is proposed for the values of the length of anchoring in the concrete of the dowel bar equal to $200 \ldots 400 \mathrm{~mm}$.

$$
D_{c r} \approx 5.0 \cdot f_{c t} \cdot c \cdot d_{b} \cdot \frac{c}{0.66 c+d_{b}},
$$

Where 5 - empirical coefficient;

$f_{c t}$ - Standard tensile strength of concrete;

$c=100 \mathrm{~mm}-$ Concrete cover (see fig. 6);

$$
d_{b} \text { - Diameter of the pin-rod }
$$

\section{Methodology for assessing the load- bearing capacity of the slab slinging unit during tests}

The bearing capacity of the slinging unit in the slab was determined in accordance with the Technical Recommendations TR 94-2003 "Slinging loops of precast concrete and reinforced concrete structures, design, calculation and testing". NIIZHB. Moscow. The force acting on the slinging unit should be made from the condition

$$
N \leq N_{s, u l t},
$$

Where $N$ - force acting from assembly loads on the anchor rod-dowel of the slinging unit; $N_{s, u l t}=D_{\text {cor }}-$ Ultimate force perceived by the anchor rod-dowel (dowel resistance of the anchor rod, corresponding to the splitting of the concrete cover - see formula (2);

Force $N$ was determined by the formula

$$
N=G \cdot \tilde{\mathrm{a}}_{d} \cdot \tilde{\mathrm{a}}_{a} \cdot \tilde{\mathrm{a}}_{f} \cdot \tilde{\mathrm{a}}_{a d},
$$

Where $C$ - self-weight force;

$\tilde{\mathrm{a}}_{d}$ - Dynamic coefficient during lifting and installation taken equal to 1.4;

$\tilde{\mathrm{a}}_{a}$ - coefficient taking into account the increase in the force acting on the anchor roddowel when the cargo sling deviates from the vertical by an angle á from $0^{\circ}$ to $45^{\circ}$, taken equal: 1,0 - at á $=0^{\circ} ; 1,4-$ at á $=45^{\circ}$. For intermediate values of the angle á, the values of $\tilde{a}_{a}$ are taken by linear interpolation (deviation of the cargo sling from the vertical by an angle á greater than $45^{\circ}$ is not allowed).

$\tilde{\mathrm{a}}_{a d}$-Coefficient taking into accounts the suction (sticking) of the product to the pallet of the stand at the moment of the first lifting of the product;

$\tilde{a}_{f}-$ Load safety factor.

When testing the bearing capacity of the slinging unit of the slab with the test load $C_{\text {cont }}$, it is taken equal to the force $N$. The value of the control load $C_{\text {cont }}$ includes the load from the own weight of the product (plate) per one slinging unit.

Tests of loopless slinging units consisted in lifting the slab by gripping the anchor rods of these units with hooks. The slab was additionally loaded in such a way as to provide the force in the anchor rods of the slinging units from the required control load in terms of bearing capacity. The slab with an additional weight, captured by the anchor rods of all 4 slinging nodes, was lifted 6 times until it was completely detached from all points of support. With each lifting of the slab, exposure was carried out for 10 minutes, and then it was gradually lowered until the cargo slings were loosened. At each exposure of the slab under 
load, the locations of the slinging units were inspected.

Taking into account the preliminary calculations according to the methods given in subsections II.1 and II.2, the diameters of the reinforcing rods-pins in the slinging nodes (Fig. 5) of the slabs were taken: $\varnothing 20 \mathrm{~A} 240$ - for slabs up to $6.0 \mathrm{~m}$ long; $\emptyset 22 \mathrm{~A} 240$ - - for slabs with a length of 6.0 to $7.2 \mathrm{~m}$.

Tests of loopless slinging assemblies against assembly loads were carried out on two plates: the first plate was $5.9 \mathrm{~m}$ long and designed for a unified load of $800 \mathrm{kgf} / \mathrm{m}^{2}$; the second - with a length of $7.2 \mathrm{~m}$ - under a load of $600 \mathrm{kgf} / \mathrm{m}^{2}$.

The strength of the concrete of the tested slabs and the embedding of the slinging units were determined on the day of testing with a Silvep Schmidt sclerometer of the PCN type (shock-impulse method) and an ONIKS-OS device with an electronic unit (for determining the strength and class of concrete by the method of shearing off with shearing).

\section{RESULTS AND ITS DISCUSSION}

The results of tests on the bearing capacity of slinging assemblies arranged in hollow-core slabs without formwork are given in table. During the tests, no cracks were found in the sections of the slinging nodes and deformations of the anchor rods of the dowels in these nodes. After testing the slinging assemblies for assembly loads, the slabs themselves were tested for control operational loads. These slabs are accepted as having passed the load-bearing tests.

Based on the research results, the following conclusions were drawn.

1. The proposed slinging units, arranged in hollow-core slabs without formwork molding in accordance with Fig. 5, passed control tests for installation loads without damage to the areas of these nodes.

Table. Test results of slab slinging units

\begin{tabular}{|c|c|c|}
\hline Slab length, $\mathrm{m}$ & 5,9 & 7,2 \\
\hline Strength of concrete slab, MPa & 28,8 & 31,2 \\
\hline Concrete strength of the sling assembly, MPa & 24,7 & 27,3 \\
\hline Self-weight of the slab, kN & 20,46 & 24,92 \\
\hline $\begin{array}{c}\text { The total value of the bearing capacity of all 4 slinging units }\left(4 \cdot D_{c r}\right), \mathrm{kN}- \\
\text { see forms. (2) }\end{array}$ & 72,08 & 77,48 \\
\hline Control load $C_{\text {cont }}$ on the slab (taking into account its own weight), kN & 53,14 & 58,73 \\
\hline
\end{tabular}

2. Formula (2) given in [12] can be used to calculate the bearing capacity of slinging units arranged in hollow-core slabs without formwork, the design solutions of which are similar to the solution of the proposed slinging unit.

3. Due to the fact that the bearing capacity of the slinging unit depends on the location of 
the anchor rod-dowel along the section height of the hollow-core slab without formwork, that is, on the thickness of the concrete cover «c» - see formula (2) - it is recommended to arrange the anchor roddowel as low from the top shelf of the slab as it can be gripped by the hook of the cargo sling.

\section{CONCLUSION}

1. Based on the results of design and technological development of a loopless slinging unit with an anchor rod-dowel (Fig. 5) for hollow-core floor slabs produced using the technology of stand-off formwork molding, and pilot testing at the enterprises of JV “BINOKOR TEMIR-BETON SERVIS" "GEO-BETON TRUST", their operational suitability and the possibility of implementation at other enterprises of the country with similar production were established.

2. A loopless slinging unit with an anchor roddowel, proposed for the device in a hollowcore slab without formwork, can be used for the device in other reinforced concrete structures produced using the technology of stand-off formwork.

3. A utility model patent was obtained for the proposed structural and technological development of a slinging unit with an anchor rod-dowel for a hollow-core slab without formwork molding [13].

\section{REFERENCES}

1. Goncharova M. A., Ivashkin A. N., Kosta A. A. Selection and optimization of concrete compositions for the production of hollow-core slabs without formwork.
Construction Materials. Moscow: No. 3 (2017). -pp. 35-38.

2. Barkov Yu. V., Zakharov VF Cross-shaped loops for reinforced concrete hollow-core floor slabs without formwork bench molding. Housing construction. Moscow: No. 10 (2008). -pp. 24-27.

3. Barkov Yu. V., Golofast SI, Zakharov VF Smirnov L. Yu. Multi-hollow building product and method of its production. Patent for invention RU 2204665 C1 (20.05.2003).

4. Anferov V.A. A hollow building product and a method for its manufacture. Invention patent RU 2.263 $748 \quad \mathrm{C}_{1}$. (10.11.2005).

5. Degotkov O.V., Krivchikov A.N. Polyhollow building product and method of its manufacture. Invention patent RU 2313 639 C1 (27.12.2007).

6. Serbinovsky A.V., Pesotsky E.A., Pinevich S.S. Reinforced concrete hollow-core slab of stand-off formwork molding. Utility model patent RU 65917 U1. (27.03.2007).

7. Shashin A.F., Kalinichev N.N., Minkin B.R., Closed assembly loops in heavy concrete products. Concrete and reinforced concrete. Moscow: No. 9 (1986). -pp. 5-6.

8. Grinev V.D., Popkov Yu.V., Gil A.I. Hollow reinforced concrete slabs with modified mounting loops. Bulletin of Polotsk State University. Applied Sciences. Series F. Construction. No. 16 (2011). -pp. 67-70.

9. Ashkinadze G.N., Sokolov M.E., Martynova L.D., Lishak V.I. (USSR), Tassnos F., Tsukantas S., Plainis P., Skarpas A. (Greece). Reinforced concrete walls of earthquake-resistant buildings: Research and design bases. Moscow: Stroyizdat. (1988). -p. 504. - ISBN 5-274-00212-5.

10. Rasmussen B. H. Strength of transyezsely loaded boltsand dowels cast info 
conerete. Laboratoriet for Bygningastatik, Denmark Technical University, Meddelelse. vol. 34. №2, 1962.

11. Utesher G. and Herrmann M. Vesushe zur Ermittlung der Tragfahig Keit in beton eingespannter Rundstahldollen aus nichetrostondem austenitischem Stahi. Deutscher Ausschuss fur stahlbeton, Heft 346, Berlin, 1983, p 49-104.

12. Gustafsson P. J. and Hillerborg A. Impovements in concrete design achieved trhough the application of feacture mechanics. NATO ARW: Fracture Mechanics in conrete. Northwestern University, September, 1984.

13. Мирзаев П. Т., Умаров К. С., Мирзаев Ш. П., Шухратходжаев Ж. М. Многопустотная плита безопалубочного формования. Патент на полезную модель UZFAP01501 (29.05.2020). 